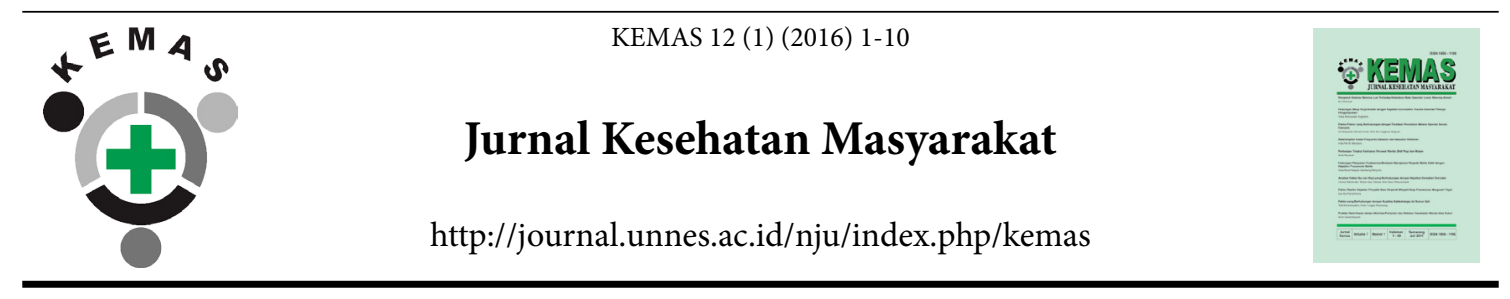

\title{
RISK FACTORS AND PREDICTIVE MODEL OF DIARRHEA IN KUPANG
}

$\operatorname{Irfan}^{\bowtie}$

Ministry of Health Polytechnic of Kupang

\section{Article Info}

Article History:

Submitted October 2015

Accepted January 2016

Published July 2016

Keywords:

Diarrhea; breast-milk; latrine type; age; family members

DOI

http://dx.doi.org/10.15294/

kemas.v12i1.4013

\begin{abstract}
Abstrct
Diarrhea is still endemic in NTT province and in Kupang City. The disease also includes as one of the 10 major diseases in Kupang City. Diarrhea prevention will work more effectively if it is conducted based on the knowledge of risk factors for diarrhea. The study aims at analyzing the risk factors of diarrhea and predictive models of diarrhea incidence in Kupang. The observational analytic research used case control design with case samples consisted of 62 patients with diarrhea in June 2015 taken by random sampling and control samples consisted of 62 children who were not listed as diarrhea patients in June 2015. The data was collected through interviews and observation. Bivariate and multivariate analyses were performed using logistic regression. Four variables that significant are age of stop getting breast milk (ASI) (OR 5.673), latrine type (OR 4.527), children age (OR 1.460) and number of family members (OR 0.484). The regression model resulted in the study is $\hat{Y}=-0.630+1.736$ age of stop drinking breast milk +1.510 latrine type + 0.379 children age -0.726 number of family members.
\end{abstract}

\section{Introduction}

Diarrhea is still a global problem for toddlers, especially for developing countries, including Indonesia. Globally, the percentage of diarrhea in causing the death is $16 \%$ (Soenarto, 2011). Diarrhea in young children is estimated to occur as many as 2.5 billion cases annually (Agtini, 2011). According to Riskesdas 2007, diarrhea is the number one cause of death in infants (31.4\%) and in toddlers (25.2\%) (Kementrian Kesehatan RI, 2014).

The numbers of morbidity and mortality from diarrhea in Indonesia are still high. Incident Rate (IR) of diarrhea continues to rise each year from $423 / 1000$ people in 2000 to $374 / 1000$ inhabitants in 2003 and $423 / 1000$ inhabitants in 2010. The state of extraordinary event (Kejadian Luar Biasa-KLB) caused by diarrhea is common in Indonesia. The 2008 outbreak of diarrhea occurred in 69 districts with 8133 cases and 239 deaths (CFR 2.94\%), and in 2009 dropped to 24 districts by 5756 people and 100 deaths (CFR 1.74\%), but in 2010 it increased to 33 districts with 4204 cases and 73 deaths (CFR 1.74\%) (Kementrian Kesehatan RI, 2014).

The incident of diarrhea in East Nusa Tenggara (NTT) province in 2013 from the total of diagnosis is $2.6 \%$, placing the province in $17^{\text {th }}$ rank nationally, while the diarrhea happening to toddlers is $4.6 \%$ (Kementrian Kesehatan RI, 2014). Likewise, diarrhea outbreak in NTT still occurs frequently, becoming the second highest frequency after the dengue fever outbreak. Diarrhea outbreak in NTT in 2010 occurred 12 times with 805 cases and CFR 1.61\% (Pusat Data dan Surveilans Kesehatan, 2011).

Diarrhea is an endemic disease in NTT and also Kupang. Although the cases of diarrhea in Kupang in 2012 and 2013 have decreased as compared to 2011, but diarrhea still includes in 10 major diseases found in Kota Kupang (DKK Kupang, 2014). In 2012, the highest IR are in Pasir Panjang Puskesmas (public health center), Naioni Puskesmas, and Alak Puskesmas. And in 2013, the cases were found in Penfui 
Puskesmas, Pasir Panjang Puskesmas, and Naioni Puskesmas. Oepoi Puskesmas always has the lowest IR in 2012 which is 6.31 cases per 100,000 people and there is 7.57 cases per 100,000 population in 2013 (DKK Kupang, 2014).

According to Subdit Pengendalian Diare dan ISPA (2011), the prevention of diarrhea can be conducted through several actions like providing breast milk, giving nutritious complementary foods, using clean water, washing hands before preparingfood, defecating feces in toilet and giving measles immunization. The prevention will be successful if it is done together by community, government, and other stakeholders. Diarrhea prevention would be more effectively conducted when the risk factors associated with the incident of diarrhea is well-understood. Based on this background, the study is conducted to analyze the risk factors and predictive models of diarrhea cases in Kupang.

\section{Method}

This study is an observational analytic research using case-control studies. The study began by classifying the population into groups of cases (patients with diarrhea) and control group (patients without diarrhea). A retrospective study was then conducted to see the risk factors of diarrhea. The data was collected from June to July 2015 in Pasir Panjang Puskesmas as a public health center with the highest incident rate (IR) of diarrhea and in Oepoi Puskesmas as a public health center with the lowest incidence rate (IR) of diarrhea in Kupang.

The dependent variable in this study is the incident of diarrhea, while the independent variable is the number of family members, children age, sex of children, birth weight of children, toddler age when they stop getting breast milk (ASI), latrine types and the condition of clean water with the scale data of both dependent and independent variables is categorical data. The category of research variables are the incident of diarrhea which is classified as patients with diarrhea and without diarrhea, the number of family members is classified into numbers of family members $>4$ and $\leq 4$ people, the age of children is classified into age $\leq 2$ years and $>2$ years, the sex of children is classified into male and female, birth weight infant is classified into birth weight $<2,500 \mathrm{~g}$ and $\geq 2500$ grams, the age of children when they stop getting breast milk is classified into breastfeeding stop at the age $\leq 1$ year and $>$ 1 year, the type of latrines is classified into plengsengan (direct defecation) and goose neck latrine, and the condition of clean water (SAB) is classified into eligible physical condition of water supply system (MS) and ineligible water supply system (TMS).

The population of the study included all patients with diarrhea in 2015. There were 62 infants with diarrhea in January-June 2015 who were recorded in the register book both in pustu and puskesmas, 38 cases in Pasir Panjang Puskesmas and 33 cases in Oepoi Puskesmas. The research samples were case sample and control samples. Case sample included 31 toddler patients with diarrhea in Pasir Panjang

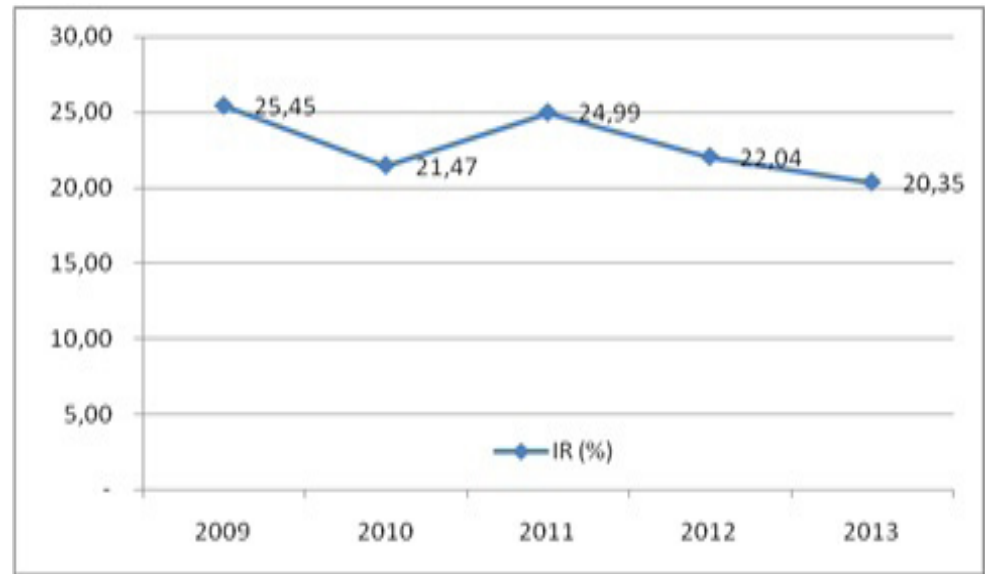

Figure 1. Incident Rate (IR) of Diarrhea in Kupang between 2009-2013 


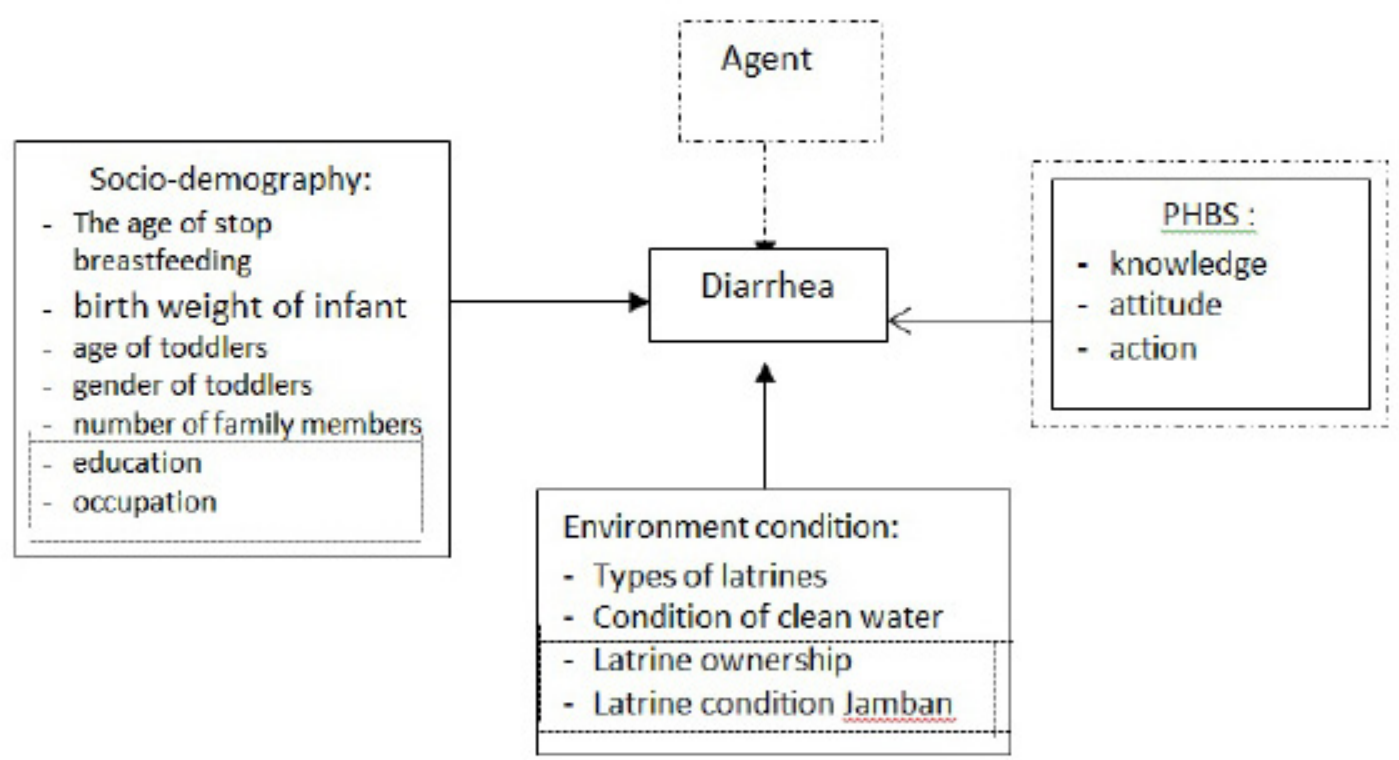

Figure 2. Research Framework

Puskemas and 31 diarrhea patients in Oepoi Puskesmas from January to June 2015. The sample size was calculated based on the below formula:

$\mathrm{n}=\mathrm{N} / 1+\mathrm{N} .(\mathrm{d})^{2}$,

$\mathrm{n}$ is sample size, $\mathrm{N}$ is the population of patients with diarrhea in each puskesmas between January-June 2015 and $d$ is the degree of culpability of 0.01 . From the calculation, the sample size in Oepoi Puskesmas is 31 and for the ease, 31 patients with diarrhea were taken in Pasir Panjang Puskesmas. The samples were taken using random sampling technique.

The control samples were toddlers who were not recorded in the register book of Oepoi Puskesmas and Pasir Panjang Puskesmas and in Pustu working area as patients with diarrhea in January-June 2015, neighboring houses or people around diarrhea patients, and children mothers who are responsible for the care of children willing as respondents will be interviewed to obtain the research data. Case and control groups were compared to $1: 1$ so the number of cases of diarrhea was 62 children patients with diarrhea and 62 control children patients without diarrhea.

The primary data was obtained by direct interviews with respondents using questionnaires and direct observation of physical condition of houses in cases and controls groups using a checklist. Secondary data included name, age, name of family head $(\mathrm{KK})$ and home addresses of diarrhea patients were obtained from register book of Oepoi and Pasir Panjang Puskesmas and village clinics in the working area.

The research data was then edited, processed and presented descriptively using MS Word and MS Excel in the form of tables, and was then analyzed analytically using SPSS 16 with logistic regression with enter method (a 0.05). The bivariate analysis was conducted to see the relationship between independent and dependent variables, whereas multivariate analyzes were performed to simultaneously see the influence of the independent variables on the dependent variable to create predictive models and diarrhea incident in Kupang. The variables used in the multivariate analysis were the independent variables in the bivariate analysis which had a value of $\mathrm{p}<0.25$ or had a relationship with the incidence of diarrhea.

\section{Results and Discussion}

This study reveals that most family have family members of $\leq 4$ people as compared to the $>4$ people both in the case group (67.7\%) and control group (54.8\%). The age of diarrhea patients in case group and control group are > 2 years which is $59.7 \%$ in case group and $83.9 \%$ in control group. In distribution of sexes, male 
Table 1. Variable Frequency Distribution of Research Group from Cases and Controls groups of Diarrhea in Kupang in 2015

\begin{tabular}{llllllll}
\hline \multirow{2}{*}{ Research Variables } & \multicolumn{2}{l}{ Case } & \multicolumn{3}{l}{ Control } & \multicolumn{2}{l}{ Total } \\
\cline { 2 - 8 } & & $\mathbf{N}$ & $\mathbf{\%}$ & $\mathbf{N}$ & $\mathbf{\%}$ & $\mathbf{N}$ & $\%$ \\
\hline Family Members & $>4$ people & 20 & 32,3 & 28 & 45,2 & 48 & 38,7 \\
& $\leq 4$ people & 42 & 67,7 & 34 & 54,8 & 76 & 61,3 \\
Child Age & $\leq 2$ years old & 25 & 40,3 & 10 & 16,1 & 35 & 28,2 \\
& $>2$ years old & 37 & 59,7 & 52 & 83,9 & 89 & 71,8 \\
Sex & Male & 32 & 51,6 & 29 & 46,8 & 61 & 49,2 \\
& Female & 30 & 48,4 & 33 & 53,2 & 63 & 50,8 \\
Birth Weight & $<2500$ gr & 17 & 27,4 & 16 & 25,8 & 33 & 26,6 \\
\multirow{4}{*}{ Stop Drinking Breast Milk } & $\geq 2500$ gr & 45 & 72,6 & 46 & 74,2 & 91 & 73,4 \\
& $\leq 1$ year & 25 & 40,3 & 6 & 9,7 & 31 & 25,0 \\
Types of Latrines & $>1$ year & 37 & 59,7 & 56 & 90,3 & 93 & 75,0 \\
& direct/ & 29 & 46,8 & 9 & 14,5 & 38 & 30,6 \\
Condition of Water System & Swan neck & 33 & 53,2 & 53 & 85,5 & 86 & 69,4 \\
& Ineligible & 20 & 32,3 & 20 & 32,3 & 40 & 32,3 \\
\hline Total & Eligible & 42 & 67,7 & 42 & 67,7 & 84 & 67,7 \\
\hline
\end{tabular}

Sources: Primary data

patients dominate female patients in case group. However, the number of female patients is a lot more in control group, as shown in Table 1.

Table 1 also shows that the birth weight in both groups of case and control are more likely to have low birth weight ( $>2500$ g), i.e $72.6 \%$ in case group and $74.2 \%$ in control group. The age when the children stop drinking breast milk is mostly in the aged $>1$ year. In this study, the use of goose neck latrine is more common, but the number of eligible or not eligible toilets conditions is the same both in the case and control.

The result of bivariate analysis is shown in Table 2. The bivariate analysis produces variables which have a value of $p<0.25$, there are four variables: the number of family members, child age, age of stop drinking breast milk and type of latrines. These four variables will be used in the multivariate analysis.

Based on multivariate analysis using logistic regression of enter method, it is known that there are four independent variables which influence the incident of diarrhea, namely age of stop drinking breast milk (OR 5.673), type of latrine (OR 4.527), children age (OR 1.460), and the number of family members (OR 0.484), as shown in Table 3.

The percentage of accuracy in classifying observation models is $70.2 \%$, meaning that there are 87 observations proper classification by logistic regression models of a total of 124 observations. The obtained model of regression equation is: $\mathrm{Y}=-0.630+1.736$ age of stop drinking breast milk +1.510 type of latrine + 0.379 the children age -0.726 number of family members

Based on the results of logistic regression analysis, enter method shows that there are four independent variables that affect the incidence of diarrhea in Pasir Panjang and Oepoi Puskesmas namely the age of stop drinking breast milk, type of latrine, children age and number of family members. The age of stop drinking breast milk is mostly $>1$ year old both in case and control groups. Based on logistic regression, the age of stop drinking breast milk affects the incidence of diarrhea with OR 7.801, which means children who stop drinking breast milk at $\leq 1$ year of age are at risk of suffering 
Table 2. Results of Research Variables Bivariate Analysis on Case and Control Groups in Kupang in 2015

\begin{tabular}{|c|c|c|c|c|}
\hline Research Variables & & $\begin{array}{l}\text { Value of } \\
p\end{array}$ & OR & CI 95\% \\
\hline \multirow[t]{2}{*}{ Family Members } & $>4$ people & 0,140 & 0,578 & $0,278-1,201$ \\
\hline & $\leq 4$ people & & & \\
\hline \multirow[t]{2}{*}{ Child Age } & $\leq 2$ years old & 0,002 & 3,514 & $1,508-8,187$ \\
\hline & $>2$ years old & & & \\
\hline \multirow[t]{2}{*}{ Sex } & Male & 0,590 & 1,214 & $0,600-2,456$ \\
\hline & Female & & & \\
\hline \multirow[t]{2}{*}{ Birth Weight } & $<2500 \mathrm{gr}$ & 0,839 & 1,086 & $0,490-2,410$ \\
\hline & $\geq 2500 \mathrm{gr}$ & & & \\
\hline \multirow{2}{*}{$\begin{array}{l}\text { Stop drinking breast } \\
\text { milk }\end{array}$} & $\leq 1$ year & 0,000 & 6,306 & $2,360-16,854$ \\
\hline & $>1$ year & & & \\
\hline \multirow[t]{2}{*}{ Types of Latrines } & direct/ & 0,000 & 5,175 & $2,179-12,291$ \\
\hline & Swan neck & & & \\
\hline \multirow{2}{*}{$\begin{array}{l}\text { Condition of Water } \\
\text { System }\end{array}$} & Ineligible & 1,000 & 1,000 & $0,471-2,123$ \\
\hline & Eligible & & & \\
\hline
\end{tabular}

Sources: Primary data

from diarrhea 7,801 times greater than children who stop breastfeeding at age $>1$ year. This study finds that children up to the age of 1 year old still who are drinking milk is only $25 \%$. It is also similar to research in Africa, Asia, Latin America and the Caribbean by Black et al. i.e which reveals that less than $25 \%$ children are still drinking breast milk in 6-11 months old infants (Lamberti, 2001).

A study in Qatar states that infants who are exclusively breast-fed is only $59.3 \%$ (Bener, 2011), whereas in Pemalang is 59.5\% (Raharjo, 2014). Babies who are not breastfed exclusively are affected on diarrhea shigellosis with OR 4.352, which means babies who are not breastfed exclusively are at risk of diarrhea shigellosis 4.352 times greater than babies who drink breast milk exclusively (Abdullah, 2012). Likewise, Ehlayel study (2009) finds that the exclusively breast-fed infants have lower risk of suffering from diarrhea than those who are not exclusively breastfed or drinking both breast milk and formula. This means that exclusive breastfeeding can reduce the risk of diarrhea and infants with the age $>1$ year old have lower risk of suffering from diarrhea. According to (Lamberti, 2011), breast milk is a source of natural immunity to fight diarrhea. Breast milk can guarantee obtainment of appropriate nutrition for infants and also non-specific immunity because of breast milk content is very complete as needed by the infants (Lamberti, 2011).

The importance of breastfeeding is not only for preventing diarrhea, but in general, for reducing morbidity and mortality because of infectious disease in children and also minimizing the numbers of hospitalizations and deaths due to diarrhea, other respiratory tract infections, lower respiratory infections and allergies as well as no negative impact on growth (Horta et al, 2013). The previous metaanalysis study of infants aged 0-5 months has proven that infants who are not exclusively breastfed have an increased risk of death from diarrhea by 10.52 times greater as compared to those who are exclusively breastfed, and children aged 6-23 months who are not breastfed have the risk of death from diarrhea 2.18 times greater as compared to children who receive breast milk (Lamberti, 2011). Similarly, the research by Prameswari (2009) finds that the duration of exclusive breastfeeding has a significant correlation with the frequency of occurrence of upper respiratory tract infections with negative relationship which means that 
Table 3. Results of Multivariate Test of Research Variables

\begin{tabular}{llllllll}
\hline \multicolumn{2}{l}{ Variables in the Equation B } & S.E. & Wald & Df & Sig. & $\operatorname{Exp}(\mathbf{B})$ & $\mathbf{9 5} \% \mathbf{C I}$ \\
\hline Stop drinking breast milk & 1.736 & .560 & 9.603 & 1 & .002 & 5.673 & $1,893-17,003$ \\
Types of Latrine & 1.510 & .481 & 9.851 & 1 & .002 & 4.527 & $1,763-11,622$ \\
Children Age & .379 & .517 & .536 & 1 & .464 & 1.460 & $0,530-4,026$ \\
Family Numbers & -.726 & .432 & 2.815 & 1 & .093 & .484 & $0,207-1,130$ \\
Constant & -.630 & .303 & 4.317 & 1 & .038 & .532 & \\
\hline Soun & & & & & &
\end{tabular}

Sources: Primary data

the longer the exclusive breastfeeding is done, the lower the frequency of upper respiratory tract infections will happen in children and the shorter exclusive breastfeeding then the higher the frequency of upper respiratory tract infections in children. Breastfeeding is not only good for the prevention of diarrhea and other diseases in young children, but also breastfeeding should be given more frequently in infants who have diarrhea. Such action aims to provide nutrients so that the infants remain strong and to prevent weight loss due to diarrhea (Subdit Pengendalian Diare dan ISPA, 2011).

Breast milk is better than formula in terms of nutrition contained and also in terms of microbiological substances. Breast milk is easier to be kept clean and not contaminated with bacteria as compared with formula. The prevalence of infant formula contaminated with the bacteria is still rarely investigated and reported, but according to Jayarao in Suwito (2010), the prevalence of infant formula contaminated by Clostridium Jejuni is $2 \%$, $2,4 \%$ by Escherichia coli, $2.8 \%$ by Listeria monocytogenes, $60 \%$ Salmonella sp and $1.2 \%$ by Yersinia enterolitica (Suwito, 2010). Additionally, the way to sterilize milk bottle is not good as well as risk factors for diarrhea (Ehlayel, 2009).

Breastfeeding, in addition to providing short-term benefits, also provides long-term benefits including: slightly lowering systolic blood pressure, reducing the risk of diabetes mellitus type 2 , reducing the risk of overweight and obesity, and statistically improving intellectual ability (Horta, 2013). Besides health benefits, breastfeeding can provide closeness and happiness between the baby and the mother, and this is good for the development of the child. Breastfeeding is also more efficient in terms of time and economy because it does not need separate budget to purchase formula, and breast milk is more easily digested by babies than formula. Sometime, infants are exposed to diarrhea due to intolerance to certain foods, including the formula, and not because of breastfeeding. Because of the benefits of breastfeeding, WHO strongly recommends exclusive breastfeeding for infants at the age of 6 months and continue it up to the baby reaching 2 years old (Horta, 2013).

The sustainability of breastfeeding provided by a mother depends on various factors. Sriningsih (2011) and Raharjo (2014) in their research find that there is a relationship among mother's education level, income level, knowledge and attitudes with exclusive breastfeeding. In Sriningsih research, it is found that $72,6 \%$ of the mothers have less knowledge about breastfeeding while $69.5 \%$ of the mothers are the same in the Raharjo's study (2014). Knowledge and attitudes of mothers about breastfeeding cannot be separated from the role of health professionals including midwives. The practice of early initiation of breastfeeding and exclusive breastfeeding practices are significantly proven to be interrelated (Raharjo, 2014). Meanwhile, according to Smith (2012) in Ichsan (2015), the sustainability of breastfeeding is the result of a complex interaction among several factors such as the obtained information, breastfeeding skills, support and experience for mothers. Further, Ichsan (2015) finds that the adequacy of milk production, working status of mothers, and family support together influence the actions of mother in successfully providing exclusive breastfeeding. Significantly, it is also revealed that women who receive the family support have the knowledge and attitude of exclusive breastfeeding which are higher than those who do not follow the family support 
program that will impact the increased action of breastfeeding (Ichsan, 2015).

The role of breastfeeding in the prevention of diarrhea has been extensively researched and proven, and the success in breastfeeding, especially exclusive breastfeeding, does not only depend on the maternal factors alone, but also involves many parties including support from other people such as husband, mother, grandmother, mother-in-law and other family members, as well as the support of health professionals, such as midwife. Therefore, the role and support of family members and health professionals for mothers must be maintained and enhanced.

The types of latrines in case and control groups in this study are mostly direct latrine, but the percentage is higher in the case group than in the control group. Based on logistic regression analysis, there is an effect between the type of latrines with the incident of diarrhea with OR 5.597, which means children who have direct/plengsengan toilet or latrine are at risk of diarrhea 5.597 times higher than children who have goose neck latrine. This study differs from previous studies which state that their risk of having a direct latrine suffers from lower diarrhea as compared to those with goose neck latrine. However, some previous studies with systematic review find two studies that state the type of latrine is significant as a risk factor for diarrhea, while two other studies state it is not significant (Adisasmito, 2007).

Latrine ownership in a previous study is found to be associated with the incident of diarrhea (Putranti, 2013), and latrine ownership is associated with socio-economic communities, education, knowledge, attitudes and customs of the people (Darsana, 2014). Research in Wereda reveals that the ownership of latrines $>2$ years has connection with the diarrhea (Anteneh, 2010). This is related to the time required by family members to familiarize themselves in utilizing and maintaining the cleanliness of the toilets. Latrine ownership, even though it is goose neck type, cannot actually reduce the risk of diarrhea if it is not supported by the clean and healthy condition for defecation.

Healthy latrines should be free from odor, have sufficient water and soap, and have no left feces around the pit so the flies will not perch and spread germs to food or utensils. Although people defecate in goose neck latrine but when the toilet hygiene is not maintained, then it is still potentially infectious of diarrhea. Good use of toilet is by utilizing it for defecation of whole family members, including children and babies. Infant and children's feces should also be disposed of in toilets and latrines must be kept clean. According to Wandasari (2013), the use of toilet is significantly associated with diarrhea ( $p$ 0.005). Some mothers believe that children can defecate not in the toilet because they are still little or the mothers do not throw the baby feces in the toilet pit but in the garden or river (open defecation). It turns out that it is also a risk of diarrhea in children, such as in research in Ethiopia where children whose mothers do not throw baby feces in latrines are at risk of diarrhea 2.5 times higher as compared to children whose mothers throw baby feces in the toilet stool (Godana, 2013). Changes in the behavior of open defecation (OD) need to be done and for its success, it requires hard work and cooperation between local government, private sector and public awareness. Many people regard OD as a natural thing, as found in the study in Tanzania where $66 \%$ of respondents consider OD as a normal practice in the community, however, $84 \%$ of respondents feel that latrines could lead to the risk of disease for all members of society (Sara \& Graham, 2014 ). The ease and affordability to build the latrines become their reasons for choosing the type of latrines (Sara et al, 2014). Therefore, to change the outlook and behavior of latrine ownership, we must consider also the cost and ease aspect in building the toilet, aside from health aspects.

Proper location of latrine also affects diarrhea because the location of latrine also affects the use of latrines. The study in Ghana finds that children whose families have latrines in the house have the lowest prevalence of diarrhea $(11.1 \%)$ than where the pit is located outside the house (36\%). The use of toilet is both useful to maintain the health of environment so it does not pollute the soil and water around it and keep it clean, healthy and odorless (Wandansari, 2013). Good location will prevent flies and other animals perch on the stool 
and transmit germs from feces to humans. In addition, there other benefits of the proper use of toilet are to keep the dignity, right to privacy and safety because people do not need to go to the river or gardens for defecation, to produce compost and biogas for energy, to break the cycle of disease transmission, to reduce the odor and to improve sanitation and health WSP-EAP, 2009.

There are several types of latrines namely direct latrine, pond latrine, chemical toilets and goose neck latrine. Goose neck latrine is curved neck toilet with a hole filled with water so it will be useful as a stopper to prevent the entry and exit of odor and small animals which can transmit the germ-borne diseases in the body. Goose neck latrine is the best and recommended model. However, for the difficult areas of water, direct latrine could be an alternative choice by considering the healthy condition of latrine such as the drain holes should be closed to prevent the smell and small animals like flies and cockroaches, tank sludge must be watertight so it does not contaminate the soil and water in the vicinity and the hygiene must be maintained.

This study does not find the effect of the condition of water systems with diarrhea; it is similar with the research conducted in Tabanan that the source of drinking water has no relation with the incidence of diarrhea (Evayanti, 2014). This is different from previous research that finds people who have ineligible water facilities are at high risk and have 2,099 times higher of getting diarrhea as compared to those who have clean water (Hannif et al, 2011). Further, a research in Pemalang finds association between supply of clean water to diarrhea $(\mathrm{p}=0.001)$ (Mafazah, 2013), and research in Rembang also finds relationship between quality source of clean water to the incident of diarrhea ( $\mathrm{p}=$ 0.008) (Wandansari, 2013).

The absence of clean water condition relationship with the incident of diarrhea in this study may be because the percentage of clean water conditions of both groups is the same which mostly use water from the taps. There may be other factors that have more influence on the incident of diarrhea such as low immunity in the case group which is due to breastfeeding $\leq 1$ year and type of latrine family and it can be also from poor health behaviors. As said by Danquah et al. (2014) and Oloruntoba et al. (2014) mothers' behavior of not washing their hands with water and soap after defecation is associated with the incident of diarrhea in children with an OR of 4.7.

This study reveals an effect of age of children with diarrhea occurrence at OR 1.460 , which means $\leq 2$ years old are at risk of diarrhea 1,460 times higher than children aged $>2$ years old. It is also probably related to the child's condition, that many of them have stopped drinking breast milk since before they are 1 year old. Breast milk itself is also useful in preventing morbidity and mortality from diarrhea and also in reducing the proportion of hospitalizations due to diarrhea (Horta, 2013). Previous research with systematic review also reveals that as many as one study finds a significant child age as a risk factor for diarrhea, whereas three other studies state that it is not significant as a risk factor (Adisasmito, 2007). In addition to the child's age, maternal age $<25$ years is also associated with diarrhea (Diouf, 2014). This could be linked to the mother's knowledge and social economy, i.e the greater the mother's age ( $>25$ years), the more the possibility of exposure to the information and experience on diarrhea. Therefore, they are expected to have better knowledge and actions in the prevention of diarrhea.

In this study, the cases of diarrhea are more common in men with a sex ratio of 1.06: 1, this is almost the same as research in Denpasar where sex ratio of patients with rotavirus diarrhea in hospital is 1.6:1 (Salim, 2014) and 1,03:1 in Guinea-Bissau (Molbak, 1997). This study is similar to previous studies that the bivariate test shows there is a relationship between sex and diarrhea where general cases of diarrhea in women is less than men. However, in a multivariate analysis, the influence of sex on diarrhea is not significant or it is not a risk factor of diarrhea incident (Abdullah, 2012). Guinea-Bissau study finds that men have influence with the incidence of diarrhea, but its value is nearly equal RR 1.19 (Molbak, 1997).

The number of family members $>4$ is a little better on both case and control groups. Based on logistic regression, the number of 
family members influences the diarrhea by Odd Ratio (OR) 0.468 , or the amount of family members $>4$ have risk of suffering from diarrhea 0.468 times lower as compared to people who have family members $\leq 4$. In other words, people who family members $\leq 4$ are at risk of suffering from diarrhea 2.14 times higher than those who have family members $>4$. This means that the number of family members of children $>4$ have a lower risk of getting diarrhea. The family size influencing the incident of diarrhea may also be associated with family income from more people to financially contribute to family. When the family income is increased, it will indirectly affect their health behaviors including in the prevention of diarrhea.

\section{Conclusion}

The age of drinking breast milk, type of latrine, children age and number of family members are risk factors that can be used to predict the incidence of diarrhea by regression model equation of $\hat{Y}=-0.630+1.736$ age of stop getting breast milk +1.510 latrine type + 0.379 children age - 0.726 number of family members, The dominant risk factor is age of stop drinking breast milk with OR 5.673, and is then followed by the type of latrine with OR 4.527.

A more intensive outreach to the community is needed, especially mothers who have children to exclusive breastfeeding to 0-6 months old infants, and they must still provide breastfeeding until the child is 2 years old. Besides, the health department in cooperation with the local government must be more intensive in improving community awareness about diarrhea and healthy latrines. Therefore, it is expected that the whole community can consciously build goose neck latrine.

\section{References}

Abdullah, A.Z., Arsin, A.A. \& Dahlan, L. 2012. Faktor Risiko Diare Shigellosis pada Anak Balita. Jurnal Kesehatan Masyarakat Nasional, 7(1): 16-21.

Adisasmito, W. 2007. Faktor Risiko Diare pada Bayi dan Balita di Indonesia: Systematic Review Penelitian Akademik Bidang Kesehatan Masyarakat. MAKARA Kesehatan, 11(1): 1-10.

Agtini, M.D. 2011. Morbiditas dan Mortalitas Diare pada Balita di Indonesia Tahun 2000-
2007. Buletin Jendela Data dan Informasi Kesehatan, 2(2): 25-32.

Anteneh, A., Kurnie, A. 2010. Assesment of Impact of Latrine Utilization on Diarrhoeal Diseases in the Rural Communicty of Hulet Ejju Enessie Woreda, East Gojjam Zone, Ambara Region. Ethiop J Health Dev, 24 (2): 110-118.

Bener, A., Ehlayel, M.S., Abdurahman, H.M. 2011. Exclusive Breast Feeding and Prevention of Diarrheal Diaseass: A Study in Qatar. Rev Bras Saude Matern Infant, 11(1): 83-88.

Danquah, L., wuah, E., Mensah, C.M., Agyemang. 2014. Sanitation and Hygiene Practices in Relation to Childhood Diarrhoea Prevalence: The Case of Household with Children underfive years in Ghana. Science Journal of Public Health, 2(2): 119-125.

Darsana, I.N., Mahayana, I.M.B., Patra, I.M. 2014. Faktor-Faktor yang Berhubungan dengan Kepemilikan Jamban Keluarga di Desa Jehem Kecamatan Tembuku Kabupaten Bangli. Jurnal Kesehatan Lingkungan, 4(2): 124-133.

DKK Kupang. 2014. Profil Kesehatan Kota Kupang 2013. Kupang: Dinkes Kota Kupang.

Diouf, K., Tabatabai, P., Rudolph, J., Marx, M. 2014. Diarrhoea Prevalence in Children Under Five Years of Age in Rural Burundi: an Assesment of Social and Behavioural Factors at The Household Level. Global Health Action, 7: 24895 - http://dx.doi.org/10.3402/ gha.v7.24895

Ehlayel, M.S. 2009. Protective Effect of Breastfeeding on Diarrhea among Children in a Rapidly Growing Newly Developed Society. The Turkish Journal of Pediatrics, 51(6): 527-533.

Evayanti, N.K.E., Purna, I.N., Aryana, I.K. 2014. Faktor-faktor yang Berhubungan dengan Kejadian Diare pada Balita yang Berobat ke Badan RUmah Sakit Umum Tabanan. Jurnal Kesehatan Lingkungan, 4(2): 134-139.

Godana, W., Mengiestie, B. 2013. Determiant of Acute Diarrhoea among Children undr-five Years of Age in Derashe District, Southern Ethiopia. Rural and Remote Health, 13: 2329.

Hannif, Mulyani, N.S. \& Kuscithawati, S. 2011. Faktor Risiko Diare Akut pada Balita. Berita Kedokteran Masyarakat, 27(1): 10-17.

Horta, B.L. \& Victoria, C. 2013a. Short-term Effect of Breastfeeding: A Systematic Review on the Benefits of Breastfeeding on Diarrhoea and Pneumonia Mortality. Geneva: WHO.

Horta, B.L. \& Victoria, C. 2013b. Long-term Effect of Breastfeeding: A Systematic Review. Geneva: WHO.

Ichsan, B., Salimo, H. \& Soebijanto, H.A.A. 2015. Keefektifan program Kelompok Pendukung 
Ibu dalam Mengubah Perilaku Ibu Menyusui. Jurnal KEMAS, 10(2): 186-194.

Kementrian Kesehatan RI. 2014. Profil Kesehatan Indonesia Tahun 2013. Jakarta: Kemenkes RI.

Lamberti, L.M., et al. 2011. Breastfeeding and the Risk for Diarrhoea Morbidity and Mortality. BMC Public Health, 11(3): 15.

Mafazah, L. 2013. Keersediaan Sarana Sanitasi Dasar, Personal Hygiene ibu dan Kejadian Diare. Jurnal KEMAS, 8(2): 176-182.

Molbak, K., Jensen, H., Ingholt, L. \& Aaby, P. 1997. Risk Factors for Diarrheal Disease Incidence in Early Childhood: A Community Cohort Study from Guinea-Bissau. American Journal of Epidemiology, 146(3): 273-282.

Oloruntoba, E.O., Folarin, T.B., Ayede, A.I. 2014. Hygiene and Sanitation Risk Factors of Diarrhoeal Disease among under-five Children in Ibadanm Nigeria. African Health Sciences, 14(4): 10-15.

Prameswari, G.N. 2009. Hubungan Lama Pemberian ASI secara Eksklusif dengan Frekuensi Kejadian ISPA. Jurnal KEMAS, doi: http:// dx.doi.org/10.4314/ahs.v14i4.32, 5(1): 27-33.

Pusat Data dan Surveilans Kesehatan. 2011. Situasi Diare di Indonesia. Buletin Jendela Data dan Informasi Kesehatan, 2(2): 1-18.

Putranti, D.C.M.S., Sulistyorini, L. 2013. Hubungan antara Kepemilikan Jamban dengan Kejadian Diare di Desa Karangagung Kecamatan Palang Kabupaten Tuban. Jurnal Kesehatan Lingkungan, 7(1): 54-63.
Raharjo, B.B. 2014. Profil Ibu dan Peran Bidan dalam Praktik Inisiasi Menyusu Dini dan ASI Eksklusif. Jurnal KEMAS, 10(1): 53-63.

Salim, H., et al. 2014. Risk Factor of Rotavirus Diarrhea in Hospitalized Children in Sanglah Hospital, Denpasar: A Prospective Cohort Study. BMC Gastroenterology, 14: 54-59.

Sara, S., Graham, J. 2014. Ending Open Defecation in Rural Tanzania: Which Factors Facilitate Latrine Adoption?. Int $J$ Environ Res Publich Health, 11: 9854-9870; doi:10.3390/ ijerph110909854.

Soenarto, S.S. 2011. Vaksin Rotavirus Untuk Pencegahan Diare. Buletin Jendela Data dan Informasi Kesehatan, 2(2): 33-38.

Sriningsih, I. 2011. Faktor Demografi, Pengetahuan Ibu tentang Air Susu Ibu dan Pemberian ASI Eksklusif. Jurnal KEMAS, 6(2): 100-106.

Subdit Pengendalian Diare dan Infeksi Saluran Pencernaan. 2011. Pengendalian Diare di Indonesia. Buletin Jendela Data dan Informasi Kesehatan, 2(2): 19-24.

Suwito, W. 2010. Bakteri yang sering Mencemari Susu: Deteksi, Patogenesis, Epidemiology, dan Cara Pengendaliannya. Jurnal Litbang Pertanian, 29(3): 96-100.

Wandansari, A.P. 2013. Kualitas Sumber Air Minum dan Pemanfaatan Jamban Keluarga dengan Kejadian Diare. Jurnal KEMAS, 9(1): 24-29.

WSP-EAP. 2009. Informasi Pilihan Jamban Sehat. Jakarta: World Bank Office Jakarta. 